\title{
Metastatic Extraskeletal Ewing Sarcoma
}

National Cancer Institute

\section{Source}

National Cancer Institute. Metastatic Extraskeletal Ewing Sarcoma. NCI Thesaurus. Code C8801.

An Ewing sarcoma of the soft tissues which has spread from its original site of growth to another anatomic site. 